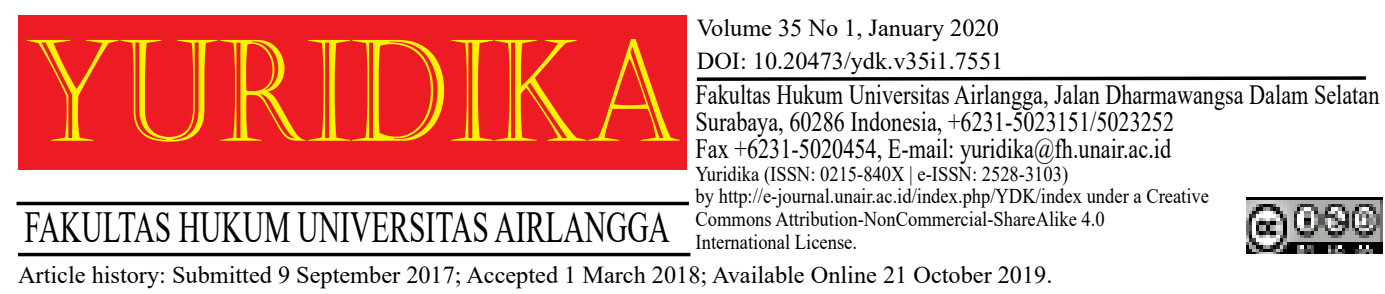

\title{
Authorities of Preparation and Hospitality of Applications for Post-Conditions Post-Decision of Constitutional Court
}

\author{
Nur Basuki Minarno \\ nurbasuki.m@fh.unair.ac.id \\ Universitas Airlangga
}

\begin{abstract}
The objective of Pre-Trial is basically to provide justice rights protection from abuse of power and the arbitrary actions of law enforcement officers. Pre-Trial is as the guard for the realization of due process of law. Hence, its authority is not limited to Article 77 of the Criminal Law Procedural Code and the decision of Constitutional Court No.21/PUU-XII/2014. The dismissal of Pre-Trial appeal as provided for in article 82 paragraph (1) sub-paragraph $d$ of the Criminal Law Procedural Code and the decision of the Constitutional Court No.102/PUU-XII/2015 do not have a sufficient rational basis. Pre-Trial and principal case examination should not terminate each other. Conversely, the result of Pre-Trial will be used as a reference to analyze whether evidence used in the principal case examination is conducted properly or not. Thus, when a Pre-Trial examination is underway, the chief of a judge of the district court must adjourn the principal review of his case.
\end{abstract}

Keyword: Pre-Trial; Due Process of Law; Constitutional Court.

\section{Introduction}

In general, a country based on law, all steps of every Indonesian citizen and his apparatus must be based on the provisions of the applicable law. ${ }^{1}$ In-Law Number 8 of 1981 concerning Criminal Procedure Law (from now on referred to as KUHAP), it recognizes several terms, namely the suspect, suspect, defendant, and convict. Suspected terms and suspects at the time of the preliminary examination (investigation), the defendant's term at the time of the hearing at the hearing, as for the term the convict was found when the defendant was found guilty by a decision that had permanent legal force. At the position of suspect or defendant, King argues that:

${ }^{1}$ Bastionto Nugroho, 'Peranan Alat Bukti Dalam Perkara Pidana Dalam Putusan Hakim Menurut KUHAP' (2017) 32 Yuridika <https://e-journal.unair.ac.id/YDK/article/view/4780/pdf_1>.[17]. 
"When an individual is determined as a suspect or defendant in a criminal case, then the individual is essentially dealing with the state. If the individual is a citizen of the country concerned, then, in essence, he is dealing with his own country. This is a consequence of the values of the bureaucratic model in the criminal justice system. However, it must be understood that the state may only take action against individuals suspected of committing a criminal offense based solely on the limits determined by the Act". ${ }^{2}$

Determination of a suspect or defendant does not reduce his right to obtain legal protection from the state. In this regard, Friedman argues that: "The state, through its apparatus, is indeed authorized to enforce the law to anyone who is suspected of guilty. But on the other hand, the state apparatus is also obliged to protect its citizens. There is no other choice when the state is faced with this dilemma unless the state adheres to the principle of justice". ${ }^{3}$ Furthermore, Radbruch states that: "If the positive law is unfair and fails to protect the interests of the people, then the Law like this is legally flawed and does not have legal nature, because the law is in principle to uphold justice". ${ }^{4}$

Criminal procedural law was actually born as a manifestation of Article 28 I paragraph (5) of the 1945 Constitution of the Republic of Indonesia (hereinafter abbreviated as UUD NRI 1945) which guarantees and protects human rights in accordance with the principles of a democratic law so that the provisions in the criminal procedure law always must be in accordance with the principles of human rights. If it is deemed necessary to have restrictions on human rights, in Article $28 \mathrm{~J}$ paragraph (2) the 1945 Constitution of the Republic of Indonesia has affirmed that these restrictions are solely carried out to guarantee recognition and respect for the rights and freedoms of others.

Formal criminal law (Criminal Procedure Law) Throughout the history of law in Indonesia, there have only been two, namely: HIR (Het Herziene Inlandsch Reglement) and Law No. 8 of 1981 concerning Criminal Procedure

${ }^{2}$ M. King, A Framework of Criminal Justice (Croom Helm 1981).[45].

3 Lawrence M. Friedman, 'Roads to Democracy' (2005) 33 Syracuse J. Int'l L. \& Com.[51-52].

4 Gustav Radbruch, 'Statutory Lawlessness and Supra- Statutory Law' (2006) 26 Oxford Journal of Legal Studies <https://www.jstor.org/stable/3600538?seq=1\#metadata_info_tab_contents>.[1-11]. 
Law or commonly referred to as "KUHAP". In both of these rules, regulating the central values of socio-political, socio-philosophical, and socio-cultural values of Indonesian people. ${ }^{5}$ When the HIR (Het Herziene Inlandsch Reglement) is still a criminal procedural law in Indonesia, the nuance of law enforcement feels full of violations of human rights values. In the HIR, criminal law enforcement is more focused on government power. ${ }^{6}$ The act of arrest and detention by law enforcement officers is carried out without strict procedural basis, and there is no time limit, the suspect or defendant is seen as an object of examination (inquisitor). As a product of the work of the Indonesian nation, the Criminal Procedure Code has provided enlightenment and certainty of guarantees, recognition, and protection of human rights. All forms of oppression of the rights of suspects are automatically reduced by themselves. The principle of presumption of innocence, which initially was merely a slogan, could eventually function again as a protective pillar for suspects and defendants. No longer looking at a suspect or defendant as an object of examination (inquisitor), but as the subject of an examination (accusator).

The purpose of the promulgation of the Criminal Procedure Code can be known through the KUHAP Implementation Guidelines issued by the Minister of Justice as follows:

"The purpose of criminal procedure is to seek and obtain or at least approach material truth, is the truth as complete as possible from a criminal case by applying the provisions of criminal procedural law honestly and precisely in order to find out who the perpetrator can be charged with violation of law, and subsequently requesting an examination and decision from the court to find out whether it has been proven that a criminal offense has been committed and whether the accused person can be blamed".

The above description has sufficiently provided an explanation of the purpose and function of the criminal procedure law, namely finding and finding the truth, giving

\footnotetext{
${ }_{5}^{5}$ Marcus Priyo Gunarto, 'Asas Keseimbangan Dalam Konsep Rancangan Undang-Undang Kitab Undang-Undang Hukum Pidana’ (2012) 24 Mimbar Hukum <https://jurnal.ugm.ac.id/jmh/ article/view/16143>.[83].

${ }^{6}$ Umi Enggarsasi, 'Dasar Dan Prosedur (Kajian Terhadap Kitab Undang-Undang Hukum Acara Pidana)' (2004) 19 Perspektif <http://jurnal-perspektif.org/index.php/perspektif/article/ view/260>.[1].
} 
a decision by the judge, and implementing the Decision.

Some important things have been contained in the Criminal Procedure Code that was not previously regulated in the HIR, including:

1. Fast, Simple and Low-Cost Principles of Justice;

2. Functional Differentiation Principles;

3. Principle of the Presumption of Innocence;

4. Principle of Opportunity;

5. Principles of Public Court Examination;

6. The Principle of Everyone Treated Equally in Front of Judges;

7. Principles of Limitation of Detention;

8. Principles of Mutual Coordination;

9. Suspects or Defendants Eligible to Get Legal Aid;

10. Redress and Rehabilitation Mechanisms;

11. Principles of Accusator and Incisors (Accusatoir and Inquisitor);

12. Presence of a pretrial institution.

Pre-trial existence is new things in the world of Indonesian justice. Pretrial is one of the new institutions introduced by the Criminal Procedure Code, placed in Chapter X of the First Section, as one part of the scope of the judicial authority for the District Court. ${ }^{7}$ Pre-trial institutions are not independent judicial institutions. The existence of a pretrial institution is a unit that is inherent in the District Court. Therefore it can only be found at the District Court level as a task force that is not separate from the District Court. It is not outside, in addition to or parallels to the District Court; it's just under the leadership and supervision and guidance of the Chair of the District Court.

The teaching of human rights developed rapidly in Indonesia, which was marked by amendments or changes to the 1945 Constitution of the Republic of Indonesia. The consequences of the recognition of human rights in the constitution directly impacted the often proposed material testing of the law because it was contrary to human rights, especially human rights. The protection of human rights today is one of the instruments used to test whether a law is by the constitution or not. KUHAP is an example of a law that has often been petitioned for judicial review because it is deemed incompatible

\footnotetext{
2009).[1].

7 M Yahya Harahap, Pembahasan Permasalahan Dan Penerapan KUHAP (Sinar Grafika
} 
with current legal needs, especially the protection of the rights of suspects/defendants from abuse of authority or arbitrary acts of law enforcement officers.

In addition to the Criminal Procedure Code that is considered unable to fulfill the rights of suspects/defendants from acts of abuse of authority or arbitrary actions by law enforcement officials, the concepts and norms in the Criminal Procedure Code are vague or unclear. Unclear, ambiguity over the concepts and norms results in the emergence of legal uncertainty and unfair treatment when the norm is manifested in concrete events. Failure to realize legal certainty and fair treatment, the state is considered a failure in protecting its citizens.

KUHAP as a formal criminal law (event) is intended to provide protection to the public from abuse of authority or arbitrary actions of law enforcement officers, but in the formulation of norms it does not heed the principle of lex certa (clear) and lex stricta (definite), which results in uncertainty the law is contrary to Article 28 D paragraph (1) of the 1945 Constitution of the Republic of Indonesia and can lead to arbitrariness which is clearly contrary to the principle of due process of law as referred to in Article 1 paragraph (3) and Article 28I paragraph (5) of the 1945 Constitution of the Republic of Indonesia.

The 1945 Constitution of NRI guarantees legal certainty and justice. Article 28D paragraph (1) of the 1945 Constitution of the Republic of Indonesia has stated "every person has the right to recognition, guarantee, protection, and fair legal certainty and equal treatment before the law". If there are norms of KUHAP that are without legal certainty (rechtsonzekerheid) and unfair (ongerichtigheid) then the said matter is declared unconstitutional. The pretrial institution is essentially an institution that has the authority to examine the legitimacy of the use of forced efforts by law enforcers, all of which is to provide protection of human rights for acts of abuse of authority and arbitrary actions by law enforcement officers. In proof of the pretrial, the suitability of the process of using forced efforts will be assessed by the procedures determined by law.

The Criminal Procedure Code has determined the authority of the PreJudicial Institution as stipulated in Article 1 number 10, which states: A pretrial is 
the authority of the District Court to examine and decide:

1. Whether or not an arrest or detention is valid;

2. Valid or not the termination of investigation or termination of prosecution;

3. Request for compensation or rehabilitation by the suspect or his family or other parties or their proxies whose case is not brought to trial.

The provisions of Article 1 number 10 are further confirmed through Article 77 of the Criminal Procedure Code which states that: The district court has the authority to examine and decide, by the provisions stipulated in this law about:

1. The legality of whether arrest, detention, termination of investigation or termination of prosecution;

2. Compensation and rehabilitation for a person whose criminal case is stopped at the level of investigation or prosecution.

The authority of the Pre-Judicial Institution as stated in Article 77 of the Criminal Procedure Code, through the Decision of the Constitutional Court No. 21/ PUU-XII/2014 has expanded the authority of the Pre-Judicial Institution, including the determination of suspects. Previously the expansion of the authority of the Pre-Judicial Institution by the Constitutional Court, by the pretrial jurisprudence also included assessing the right to search and seizure; this was done through interpretation in Article 95 paragraph (2) of the Criminal Procedure Code, which was explicitly stated in the Explanation.

Testing of the validity of the determination of suspects by law enforcement officials (Incasu. Investigators) is indeed very necessary, because of the frequent determination of the suspects carried out due to arbitrary actions of the enforcement officers. Often the determination of suspects is political orders, especially corruption cases. There are several more Constitutional Court Decisions that have relevance to pretrial authority, namely Decision No.109/ PUU-XIII/2015 related to KPK Independent Investigators, Decision No. 102/ PUU-XIII/2015 related to the death of pretrial requests, and Decision Number 130/PUU-XIII/2015 related to submission of Notice of Commencement of Investigation (SPDP). 
In this paper, we will only examine the authority of pretrial institutions, and the Constitutional Court Decision Number 102/PUU-XIII/2015 has been right or not. The view that the Constitutional Court ruling has been final and binding (res judicata principle) so that there is no room to be criticized or responded to, is incorrect. To get in-depth answers about the scope of pretrial authority and the death of pretrial applications, a philosophical study related to pretrial authority and ratio legislation needs to be carried out by Article 82 paragraph (1) letter $d$ of the Criminal Procedure Code.

Based on the description above, then a legal issue has been formulated consisting of two parts, namely; what is the scope of the authority of the Pretrial Institution? and when the first case of the case has been delegated, and the first trial has been submitted to the subject matter in the name of the defendant/pretrial applicant, will he abort the pretrial application?

\section{Pretrial Authority}

As explained above, pretrial authority includes as stipulated in Article 1 number 10 in conjunction with Article 77 of the Criminal Procedure Code, in jurisprudence that increases the authority of pretrial to include the legitimacy of searches and seizures, and the Constitutional Court also adds pretrial authority to check the validity/determination of suspects and submission of SPDP. Based on Article 77 of the Criminal Procedure Code, jurisprudence and the Constitutional Court Decision, for now, the scope of the pretrial authority includes the following:

1. Legitimate or not arrest or detention;

2. Valid/not termination of investigation or prosecution;

3. Examination of compensation or rehabilitation of cases not submitted to the district court;

4. Legitimate searches or seizures;

5. Legitimate/invalid investigation warrant (Sprindik);

6. Legitimate or not Determination of suspects;

7. Legitimate or not SPDP.

If studied more deeply, the actions of law enforcement officials that can be classified as forced efforts in the Criminal Procedure Code are not only limited to seven above, 
there are still more actions taken by law enforcement officials that can be classified as forced efforts, namely: summons, examination of letters, and police line.

In the Criminal Procedure Code, the procedure for calling is regulated. If the summons has been done procedurally two times and the witness/suspect is not present, then the three summon can be accompanied by a forced effort to be brought before the investigator. Likewise, the letter examination. To conduct a letter inspection, the Criminal Procedure Code also regulates the procedure. While the police line, the Criminal Procedure Code does not regulate, but it is regulated in the Regulation of the Chief of Police of the Republic of Indonesia in 2012 concerning Management of Criminal Investigations. If there is a deviation from the procedure for summoning, checking letters, and the police line, is the pretrial authority authorized to decide whether to call, check the letter, and police line?

It is judging from the history of the establishment of pretrial institutions in the Criminal Procedure Code as an institution that serves to conduct supervision, both horizontal and vertical supervision. The function of this oversight in the context of safeguarding does not cause abuse of authority and arbitrary action by law enforcement officials. If one party gets non-procedural treatment from law enforcement officials, then it can apply to the pretrial institution.

In practice to enforce criminal law and to protect the constitutional rights of a citizen, criminal procedural law is used as a benchmark. Thus, criminal procedure law is a law that regulates and provides limits that can be done by the state in the process of investigation, investigation and judicial process with standard methods to enforce the law and protect individual rights during the legal process. As stated by Wasserman:

"The procedural law is designed to ensure fair and consistent legal processes which are commonly referred to as a due process of law. Each procedure in due process of law examines two things (1) whether the state has removed the life, freedom and property rights of the suspect without procedure (2) if using the procedure, whether the procedure adopted is by the due process". ${ }^{8}$

8 Rhonda Wasserman, Procedural Due Process: A Reference Guide to the United State Constitution (Santa Barbara : Greenwood Publishing Group 2004).[1]. 
Referring to the Constitutional Court Decision Number 34/PUU-XI/2013 dated March 6, 2014, the Court has affirmed that "the principle of the rule of law which has been adopted in the 1945 Constitution (vide Article 1 paragraph (3) of the 1945 Constitution) places a principle that everyone has human rights (HAM), thus requiring others, including within the state, to respect them". The Court also stated that "the obligation of the state to uphold and protect human rights by the principles of a democratic law requires that the implementation of human rights be guaranteed, regulated and outlined in legislation (vide Article 28 I paragraph (5) of the 1945 Constitution). Criminal procedural law is the implementation of the enforcement and protection of human rights as constitutional provisions in the 1945 Constitution. This is by the principle of a democratic legal state, namely due process of law. Furthermore, the Court affirmed that "Regarding law enforcement and protection of human rights which are constitutional rights based on the 1945 Constitution, in the criminal justice process experienced by a person must obtain fair legal certainty (vide Article $28 \mathrm{D}$ paragraph (1) of the 1945 Constitution). ${ }^{9}$

Enforcement of criminal law often creates problems and dilemmas related to the purpose of criminal law, namely to provide legal protection both for the public interest and the interests of criminal offenders. The development of science and society takes an important role in the practice of law enforcement, namely the need for legal protection against the public interest and the interests of perpetrators of criminal acts simultaneously, on the other hand, does not require the violation of their human rights. Therefore, the protection of human rights in the process of law enforcement must be carried out in a balanced manner by considering the public interest and the interests of the suspect or defendant. Moving on from the idea that the essence of the establishment of pretrial institutions as a supervisory institution for the creation of the due process of law, all actions of law enforcement officers who are not procedural and violate human rights can be applied to pretrial institutions.

9 Constitutional Court Decision Number 34/PUU-XI/2013 dated March 6 2014.[84-85]. 
Tests that are not procedural, non-procedural checks and non-procedural police lines can be requested for testing at a pretrial institution.

Based on the description above, it is necessary to do legal reform on the scope of the pretrial authority, namely to add 1 (one) letter again in Article 77 of the Criminal Procedure Code so that it becomes Article 77 letter c stated: "Other legal actions that conflict with applicable laws and regulations". With this provision giving wider authority to pretrial institutions as guardians of the realization of due process of law.

\section{Fall of pretrial application}

Void by law of the pretrial application is regulated in Article 82 paragraph (1) letter d of the KUHAP which is stated as follows "In the event that a case has already been examined by a district court, while an examination of a request for pretrial has not been completed, then the request is dropped". The phrase "has begun to be examined by a district court" has led to different interpretations, giving rise to legal uncertainty for suspects and third parties who have the right to file pretrial. In the practice of law enforcement, there are three interpretations which are born from the phrase "have already been examined by a district court", namely the first death of a pretrial application as of the case file is submitted to the District Court by the public prosecutor. Secondly, pretrial was killed since the first trial of the case had begun, and the third was the death of pretrial since the public prosecutor had read the indictment in a trial that was open to the public. Armed with these legal uncertainties, Article 82 paragraph (1) letter d of the KUHAP has been submitted a judicial review to the Constitutional Court and has obtained a verdict as contained in the Decision of the No.102/PUU-XIII/2015 Constitutional Court which states the following decisions:

1. To grant the Petitioner's petition in part;

2. Declare Article 82 paragraph (1) letter d of Law Number 8 of 1981 concerning Criminal Procedure Law (State Gazette of the Republic of Indonesia of 1981 Number 76, Supplement to the State Gazette of the Republic of Indonesia Number 3258) contrary to the Constitution of the Republic of Indonesia Year 1945 and does not have binding legal force as long as the phrase "a case has 
begun to be examined" is not interpreted as "a pretrial fall request when the first case has been delegated, and the first trial has been filed against the case on behalf of the pretrial defendant/applicant";

3. Refuse the Petitioner's petition for other and more;

4. Order the proper loading of this decision in the Official Gazette of the Republic of Indonesia.

The ratio of decidendi of the verdict is, in principle, in the proceedings of criminal cases, the examination of pretrial claims by examining the subject matter cannot be carried out simultaneously. However, it should be borne in mind that with regard to Article 77 of Law 8/1981, the Court has stated its stand with regard to the scope of pretrial as stated in the Court's Decision Number 21/PUUXII/2014, dated 28 April 2015, which states that pretrial include legal or whether or not the determination of suspects, searches, and confiscation as objects. That the characteristics of the object of examination as referred to in Article 77 are problems that should have been resolved and decided before entering into the examination of the subject matter so that the process is referred to as the process of examination before the judiciary or pre-trial. The Criminal Procedure Code guarantees the right of each suspect to file pretrial, as stated in Article 79 and Article 80 of Law 8/1981. Therefore, it is logical that the pretrial process should end when the examination has entered the subject matter or has entered the trial stage. In addition, the provisions of Article 82 paragraph (1) letter d of Law 8/1981 a quo are also intended to provide legal certainty so that there is no dualism of the examination results, namely between legal examinations conducted by investigators and public prosecutors with examinations suspected of criminal acts carried out by the applicant so that the pretrial is submitted (underline by me). ${ }^{10}$

The decision of the Constitutional Court Number 102/PUU-XIII/2015 is just an affirmation of the norms of Article 82 paragraph (1) letter $d$ of the Criminal Procedure Code. The presence or absence of the quo Decision has no legal problems. Legal problems occur because of some "interests" of the examining judge so that the application of Article 82 paragraph (1) letter $d$ of the

\footnotetext{
${ }^{10}$ Constitutional Court Number 102/PUU-XIII/2015.[49-50].
} 
KUHAP varies in interpretation (multi interpretation). The phrase "has begun to be examined by a district court" has very clear norms, clearly cannot be interpreted at the time of registration of the case. Referring to the systematization of arrangements in the Criminal Procedure Code where the case of prosecution to the District Court is regulated in Chapter XV of Prosecution in Article 143 of the Criminal Procedure Code while the court hearings are regulated in Chapter XVI starting from Article 145 to Article 232 of the Criminal Procedure Code by the district court "in Article 82 paragraph (1) letter d of the Criminal Procedure Code it is not appropriate if the case file is submitted to the District Court. This is in accordance with the provisions of Article 143 paragraph (1) of the KUHAP which determines: "Public prosecutors delegate cases to district courts with a request to immediately try the case with an indictment ". The phrase "with a request to immediately try the case" in Article 143 paragraph (1) of the Criminal Procedure Code is an affirmation that case delegation is not the scope of the examination in the court because case delegation is an administrative procedure before the public hearing begins. Article 153 paragraph (2) letter a KUHAP also determines that the presiding Judge presides over the examination in the court means that the hearing in the court is carried out by the Judge appointed by the Chair of the District Court as yet there is no case of judges delegation of cases is considered as an examination in court has begun.

The phrase "has begun to be examined by a district court" is also inappropriate if interpreted since the first hearing on the case because the first trial will lead to other interpretations, namely whether the pretrial death counted from the date of the first trial determined by the Panel of Judges or since the indictment was the beginning of court proceedings. Thus it is not right if the phrase "has begun to be examined by a district court" is interpreted since the first trial. The phrase "has begun to be examined by a district court" right when interpreted since the reading of the indictment by the public prosecutor. The reading of the indictment is the initial stage in a court hearing in which the prosecutor's charges are the basis for the conduct of the examination. 
The existence of Article 82 paragraph (1) letter $d$ in the presence of phrase phrases "has begun to be examined by a district court" if interpreted since the transfer of cases to the District Court will tend to be misused by the public prosecutor especially if the investigation and prosecution are carried out by the same agency. In some of the pretrial requests lately, there were often pretrial rulings which were declared null and void of pretrial applications based on Article 82 paragraph (1) letter $\mathrm{d}$ of the Criminal Procedure Code. The public prosecutor intentionally did not attend the first hearing of pretrial examinations with various reasons to provide sufficient time to prepare the case for the case even though several investigative processes had not yet been completed including by waiving the rights of the suspect, for example, to present a mitigating witness. If the phrase "has already been examined by a district court" is interpreted as "already delegated", the public prosecutor in making the indictment will be "careless" with the sole purpose of aborting a pretrial application which then the public prosecutor is authorized by the KUHAP to amend or correct the indictment has been delegated (vide Article 144 KUHAP).

This violates the principle of justice injustice (unfair trial), with the fact that the existence of Article 82 paragraph (1) letter d of the KUHAP has been used in bad faith by law enforcement officials, the provisions of Article 82 paragraph (1) letter $\mathrm{d}$ of the KUHAP should not be applied directly. The period between the submission of a pretrial application with the delegation of cases must be considered, namely if a pretrial application is filed in advance from the transfer of cases to the court, then the main examination of the case in court must be postponed until the existence of a pretrial decision.

When viewed from the ratio decidendi, the establishment of the Court is correct by stating that "... the characteristics of the object of examination as referred to in Article 77 are problems that should have been resolved and decided before entering into the examination of the subject matter, so that the process is referred to as the process of examination before the judiciary, or pre-trial". However, the Court did not grant the Petitioner's petition, "The defendant has the right to be tried by the court immediately, unless a pretrial application has been filed, waiting until 
the pretrial decision is made". ${ }^{11}$ Between ratio decidendi and the ruling made by the Court has experienced an error in concluding.

The pretrial institution is allowed to first examine whether the actions of law enforcement officers are by the authorities and procedures or the provisions in the legislation. Pre-trial verdicts are actually useful also for the interests of the principal examination of a case, for example, if evidence is obtained illegally by harming the rights of other people, then in the principal examination of the case, the evidence does not need to be re-examined because the evidence is clearly obtained by fighting illegally secured evidence. In corruption cases, this is confirmed in the provisions of Article 28 paragraph (1) of Law Number 46 of 2009 concerning the Corruption Court which determines that all evidence presented in a trial must be legally obtained based on the provisions of the legislation. How can you judge the acquisition of evidence in a way that is against the law or not if the pretrial request falls first?.

If the pretrial examination falls due to the first trial being held on the first point, there is no chance to question the validity of the evidence in the main court case. Submission of objections/exceptions as stipulated in Article 156 of the Criminal Procedure Code cannot be used because the exception material does not include objections about the validity of the evidence. The Court, in giving very superficial considerations, did not arrive at the philosophical level of the establishment of pretrial institutions in the Criminal Procedure Code. The establishment of the Court is limited to how if there is a dualism of examination, it does not come to the thought of how to avoid dualism of examination. As explained clearly by the Petitioner as one of the reasons for the judicial review that in law enforcement practices, on the one hand, the Respondent colored/delayed the pretrial hearing, on the other hand, the Respondent accelerated the transfer of cases, with the aim that the pretrial examination is canceled. Regarding the death of a pretrial request, in the practice of law enforcement, the Respondent was not present at the first trial, and there was no

11 ibid.[16-17]. 
means to file a legal action, as well as whether or not to request a postponement and how long the delay could be given. This legal vacuum was used by the Respondent to delay the time while preparing the basic delegation of his case with the aim of the premature pretrial examination. This was the attitude of unfair trial so that the existence of pretrial institutions lost their essence.

In the practice of law enforcement, unfair trials by law enforcers (Respondent) cannot be avoided, and this is a strategy/any way to win cases. The thinking of Yahya Harahap is very interesting related to the provisions of Article 82 paragraph (1) letter a KUHAP, which is three days after receiving the application. The appointed judge must determine the court day. Determination of court day, not calculated from the date of appointment of a judge by the Chair of the District Court. However, it will be counted three days from the date of receipt or three days from the date of registration in the Registrar's Office. ${ }^{12}$

From the formulation of norms, it can be drawn a principle that pretrial examinations take precedence over the judiciary, in addition to the literal understanding of pretrial itself (pre-meaning before while the court means examination in court). The program for examining pretrial applications is determined by a quick examination and a single judge who checks within seven days must decide whether to accept or reject the request. Plus the scope of the authority of the pretrial institution includes testing of authority and procedures not related to the substance (principal case) so that it is not legally grounded by having examined the subject matter making it the death of a pretrial application.

The results of pretrial examinations have an important position and are very relevant to the subject matter of the case. If in a pretrial decision, it is stated that the Order for Investigation (sprindik) is invalid, then the evidence and evidence of the results of the investigation must be declared invalid. The implication is that a person cannot be determined as a suspect by basing evidence that is declared invalid, as well as the case, may not be submitted to the court for review of the subject matter.

\footnotetext{
${ }^{12}$ M Yahya Harahap (n 7).[525].
} 
Also, there is no strong juridical basis for pretrial applications to fall out with the examination of the principal case. A pretrial application is a form of legal protection given to a suspect or a third party so that it is irrelevant if the legal protection becomes lost by examining the principal case. Pretrial is only limited to checking from the authority and procedural side, while examining the subject matter in terms of its substance, so that there is no legal basis for the provisions as Article 82 paragraph (1) letter d KUHAP. Pretrial is a solution from the legislators to test whether law enforcement officers take actions that are not by their authority and procedures. Legal protection through pretrial must be carried out until the actions of law enforcement officers are proven to be true or false because pretrial will not stop the prosecution of the subject matter. This is in line with the opinion expressed by Radbruch that "If the positive law is unfair and fails to protect the interests of the people, then a law like this is legally flawed and does not have legal nature, because the law is in principle to uphold justice". ${ }^{13}$

The existence of Article 82 paragraph (1) letter d of the Criminal Procedure Code basically only protects the interests of law enforcement agencies in implementing law enforcement or can even be used to cover up the arbitrariness of law enforcement officials so that the rules should be changed or abolished, and the government must carry out its obligations to protect its citizens in accordance with Article 28 I paragraph (4) of the 1945 Constitution of the Republic of Indonesia by supporting changes or abolition of these provisions. In addition, Article 82 paragraph (1) letter d KUHAP also does not reflect the purpose of criminal procedure law to protect and enforce the constitutional rights of suspects/defendants and third parties from legal actions of law enforcement officers. Article 82 paragraph (1) letter d KUHAP is a reflection of a legal rule that does not reflect justice so that changes must be made to provide protection as well as legal certainty to guarantee justice for suspects and third parties.

In the same principle of freedom, it means that everyone has the same basic freedoms, one of which is freedom from arbitrary actions. If law enforcement officials

\footnotetext{
${ }^{13}$ Gustav Radbruch (n 4).
} 
and the government carry out arbitrary actions, then they should get protection and recovery for the consequences of such arbitrary acts as a form of justice for those who are victims of abuse. Violations of freedom from arbitrary actions are usually born because of legislation that does not reflect the justice or lack of legal certainty to get protection for the community. The Criminal Procedure Code does provide legal protection from the arbitrary actions of law enforcement officers through pretrial, but the provisions of Article 82 paragraph (1) letter $d$ of the Criminal Procedure Code have eliminated the spirit of pretrial as a form of legal protection to bring justice to those who acted law enforcers arbitrarily. If the pretrial death is aimed at speeding up the principal examination of the case, then it is irrelevant and unfounded because the period of examination of pretrial cases is only seven days and the verdict is directly binding. Also, pretrial examinations along with the subject matter will not hinder the enforcement of criminal law because in pretrial it will only test the legality of legal actions of law enforcement officers while the case will examine whether or not the criminal offense was indicted against the defendant.

Based on the aforementioned three problems, the provisions of Article 82 paragraph (1) letter $d$ of the Criminal Procedure Code are contrary to Article 28D paragraph (1) of the 1945 Constitution of the Republic of Indonesia which stipulates that everyone has the right to fair recognition, guarantee, protection, and legal certainty and equal treatment before the law. Article 28D paragraph (1) of the 1945 Constitution requires the protection and legal certainty for every citizen, including suspects. The provisions of Article 82 paragraph (1) letter d of the Criminal Procedure Code do not reflect legal protection and certainty because pretrial requests fall only because the case has been examined by the court.

\section{Conclusion}

Pretrial as a guardian for the creation of the due process of law, the authority of pretrial does not only cover the provisions in Article 77 of the Criminal Procedure Code, jurisprudence, and the decision of the Constitutional Court but is wider than that. Article 77 of the Criminal Procedure Code needs to be added to 1 (one) letter so 
that it becomes Article 77 letter $\mathrm{c}$ which reads "other legal actions that conflict with applicable laws and regulations". Article 82 paragraph (1) letter $\mathrm{d}$ of the Criminal Procedure Code does not provide a good rational basis for the death of pretrial applications. Pretrial examinations by examining the subject matter are not mutually exclusive but are complementary. Seeing the urgency of pretrial examinations, the Chairperson of the District Court can temporarily suspend the examination of the case until completion of the pretrial examination.

\section{Bibliography}

Constitutional Court Decision Number 34/PUU-XI/2013 dated March 62014.

Constitutional Court Number 102/PUU-XIII/2015.

Bastionto Nugroho, 'Peranan Alat Bukti Dalam Perkara Pidana Dalam Putusan Hakim Menurut KUHAP’ (2017) 32 Yuridika <https://e-journal.unair.ac.id/ YDK/article/view/4780/pdf_1>.

Gustav Radbruch, 'Statutory Lawlessness and Supra- Statutory Law' (2006) 26 Oxford Journal of Legal Studies <https://www.jstor.org/ stable/3600538?seq=1\#metadata_info_tab_contents $>$.

Lawrence M. Friedman, 'Roads to Democracy’ (2005) 33 Syracuse J. Int'1 L. \& Com.

M. King, A Framework of Criminal Justice (Croom Helm 1981).

M Yahya Harahap, Pembahasan Permasalahan Dan Penerapan KUHAP (Sinar Grafika 2009).

Marcus Priyo Gunarto, 'Asas Keseimbangan Dalam Konsep Rancangan UndangUndang Kitab Undang-Undang Hukum Pidana' (2012) 24 Mimbar Hukum $<$ https://jurnal.ugm.ac.id/jmh/article/view/16143>.

Rhonda Wasserman, Procedural Due Process: A Reference Guide to the United State Constitution (Santa Barbara : Greenwood Publishing Group 2004).

Umi Enggarsasi, 'Dasar Dan Prosedur (Kajian Terhadap Kitab Undang-Undang Hukum Acara Pidana)' (2004) 19 Perspektif <http://jurnal-perspektif.org/ index.php/perspektif/article/view/260>.

HOW TO CITE: Nur Basuki Minarno, 'Authorities of Preparation and Hospitality of Applications for Post-Conditions Post-Decision of Constitutional Court' (2020) 35 Yuridika. 